\title{
Optimization of a specialized beef breeding program with a crossbreeding component
}

\begin{abstract}
Summary
A complex deterministic approach (ZPLAN) was used to optimize the breeding programs for beef breeds. For the model population 1,000 beef cows and 60,000 dual purpose Simmental cows for crossbreeding were assumed. The percentage of AI was 25\% within the beef breed and 93\% within the Simmental cows. Domestic AI beef bulls were used for crossbreeding only. The total merit index included beef traits (birth weight, 200-dayweight direct and maternal, 365-day-weight, daily gain, dressing percentage, EUROP grading score) and functional traits (calving ease, stillbirth, fertility and functional longevity).

The proportion of foreign proven and domestic AI bulls was varied as well as the number of bulls tested on stations and on contract farms. Annual monetary genetic gain and discounted profit were used to evaluate alternative breeding strategies.

Extending the number of bulls tested on stations and establishing performance testing of natural service bulls on contract farms increased the annual monetary genetic gain and the discounted profit, especially when domestic AI bulls were also used in the beef cattle breeding population.
\end{abstract}

Key Words: beef cattle, breeding program, beef traits, functional traits, total merit index, artificial insemination, performance testing

\section{Zusammenfassung}

Titel der Arbeit: Optimierung eines Zuchtprogramms für Fleischrinder mit Gebrauchskreuzung

Das Computerprogramm ZPLAN, das auf einem deterministischem Ansatz beruht, wurde für die Optimierung eines Zuchtprogramms für Fleischrinder verwendet. Für eine Modell-Population wurden 1.000 Fleischrinder Herdbuchkühe und 60.000 Fleckviehkühe (Doppelnutzung) für die Gebrauchskreuzung angenommen. Der Anteil der künstlichen Besamung (KB) betrug 25\% (Fleischrinder) bzw. 93\% (Fleckvieh). Einheimische KB-Stiere wurden in der Basissituation nur für die Gebrauchskreuzung eingesetzt. Im Gesamtzuchtwert waren die Fleischleistungsmerkmale Geburtsgewicht, 200-Tage-Gewicht, 365-Tage-Gewicht, Tägliche Zunahmen, Ausschlachtung, EUROP-Handelsklasse sowie die funktionalen Merkmale Kalbeverlauf, Totgeburtenrate, Fruchtbarkeit und funktionale Nutzungsdauer vertreten. In den Simulationen wurden der Anteil der geprüften ausländischen und inländischen KB-Stiere sowie die Anzahl von eigenleistungsgeprüften Stieren auf Station bzw. Vertragsbetrieben variiert. Der jährliche monetäre Zuchtfortschritt und der diskontierte Gewinn wurden zur Beurteilung der alternativen Zuchtprogramme herangezogen. Die Erhöhung der Anzahl der eigenleistungsgeprüften Stiere auf Station sowie die Einrichtung einer Eigenleistungsprüfung von Natursprungstieren auf Vertragsbetrieben erhöhte den jährlichen monetären Zuchtfortschritt und den diskontierten Gewinn, insbesondere in Varianten, in denen einheimische KB-Stiere auch für die Reinzucht eingesetzt wurden.

Schlüsselwörter: Fleischrinder, Zuchtprogramm, Fleischleistungsmerkmale, Funktionale Merkmale, Gesamtzuchtwert, Künstliche Besamung, Leistungsprüfung

\section{Introduction}

A large number of different beef breeds are kept in suckler herds. Some of the breeds are small-framed breeds or gene conservation breeds for extensive grassland management and maintenance. Their breeders' primary interest is the conservation of the breed and/or the breed characteristics. These are not considered here. To optimize 
the breeding programs of medium and large-framed breeds that are also used for crossbreeding, simulation studies based on a deterministic approach were carried out. In the latter breeds with foreign origin, the proportion of artificial insemination (AI) is about 25\% with predominantly foreign proven bulls being used in Austria. Domestic AI bulls are nearly exclusively used for crossbreeding with dual purpose or dairy breeds. Performance recording is carried out in suckler herds and abattoirs and to a small extent in test stations. Breeding value estimation for beef breeds only exists for slaughter traits and paternal functional traits for crossbreeding at the moment.

One aim of this study was the evaluation of annual monetary genetic gain, the genetic gains per trait and discounted profit of a scenario reflecting a somewhat optimized present situation in Austrian beef breeding. A main issue was the use of a total merit index including growth, carcass and functional traits. WILLAM et al. (2002) showed in dual purpose Simmental cattle that the inclusion of functional traits in the total merit index leads to higher genetic gains or at least to reduced negative genetic gains in these traits and to a higher annual monetary genetic gain.

Alternative breeding strategies were analyzed using the same evaluation criteria. The low percentage of AI as well as the lack of using domestic AI bulls for purebreeding lead to reduced informations for breeding value estimation. This presumably results in smaller genetic gain due to small accuracy of breeding value estimation and insufficient selection intensity. Therefore, another objective of this study was to investigate the effect of increasing the proportion of AI as well as the use of domestic bulls for purebreeding on annual monetary genetic gain and discounted profit. Additionally, the effect of improving performance testing by extending the number of bulls tested on stations and establishing performance testing of natural service bulls on contract farms was analyzed.

\section{Material and Methods}

For modelling the breeding programs the computer program ZPLAN (KARRAS et al., 1997) was used. ZPLAN is designed to optimize selection strategies in livestock breeding by deterministic calculations. It is based on a comprehensive methodology of evaluating both the genetic and economic efficiency of breeding strategies considering one cycle of selection.

The gene flow method (HILL, 1974; McCLINTOCK and CUNNINGHAM, 1974) and selection index procedures constitute the core of the program. Selection groups have to be defined which are specific for their sources of information and selection intensities. In total, 23 selection groups including domestic and foreign beef breeding stock as well as Simmental dual purpose cattle used for crossbreeding were defined. Breeding programs and their parameters are defined by the user, and the program calculates a number of criteria such as aggregate genotype, annual genetic gain for single traits, discounted returns and discounted profit for a given investment period. For the selection index part of ZPLAN the informations available for the evaluation of an individual have to be defined by type and number of relatives contributing to the index of an animal. In a first step in the program, a breeding program based on the current situation was defined and evaluated. Second, alternative breeding schemes were defined. The selection intensities were adjusted for finite population size using the approximate method of BURROWS (1972). However, ZPLAN cannot consider reduced genetic variance due to selection and inbreeding. Details about the 
methodology used in ZPLAN are described in NITTER et al. (1994) and WÜNSCH et al. (1999).

The essential input parameters (population parameters, biological coefficients and cost parameters) for the base situation are presented in Table 1. Except for the foreign proven bulls, only field weighing records (birth weight, 200-day-weight and yearling weight) are available for bulls (natural service). Foreign AI bulls were assumed to be genetically superior to domestic AI bulls (Table 1). For domestic AI bulls performance testing on stations was supposed to be compulsory following the situation of the Limousin breed in one of Austria's federal countries. Generally, the input parameters describe an optimized situation of the Limousin breed in Austria.

Table 1

Essential input parameters for modelling the breeding program (base situation) (Eingabeparameter für die Modellierung des Zuchtprogramms (Basis Situation))

\begin{tabular}{|c|c|}
\hline Population parameters & \\
\hline Beef cattle cows & 1,000 \\
\hline Simmental cows & 60,000 \\
\hline Proportion of AI (proven foreign bulls only) & 0.25 \\
\hline Proportion of AI in Simmental cows & 0.93 \\
\hline Number of bulls tested on station per year & 12 \\
\hline Number of AI bulls selected per year (proportion of domestic bulls) & $10(0.5)$ \\
\hline Average number of cows per herd & 9 \\
\hline Number of natural service bulls selected per year & 30 \\
\hline Genetic superiority of foreign bulls in 200d-weight ( $\mathrm{s}_{\mathrm{A}}=$ genetic standard dev.) & $0.55 \mathrm{~s}_{\mathrm{A}}$ \\
\hline Biological coefficients & \\
\hline Use of natural service bulls (years) & 2.8 \\
\hline Use of AI bulls (years) & 2 \\
\hline Use of cows (years) & 5.3 \\
\hline Age of domestic bulls (years) at birth of offspring & 2.5 \\
\hline Age of foreign proven bulls (years) at birth of offspring & 6.5 \\
\hline Age of cows (years) at birth of offspring & 2.8 \\
\hline Average time period between calvings (years) & 1.12 \\
\hline Proportion of losses during raising (female) & 0.15 \\
\hline Proportion of losses during raising (male) & 0.25 \\
\hline Mean generation interval in years (all selection groups) & 5.40 \\
\hline Cost parameters (EURO) & \\
\hline Weight recording costs per cow & 18.62 \\
\hline Performance test on station per bull & 446 \\
\hline Performance test on contract farm per bull ( $2 / 3$ of costs on station) & 297 \\
\hline Herd book registration per cow & 0.96 \\
\hline Inspection costs per cow & 11 \\
\hline Extra charge per foreign semen dose & 10.9 \\
\hline Interest rate return; Interest rate costs & $0.06 ; 0.04$ \\
\hline Investment period (years) & 20 \\
\hline
\end{tabular}

The supposed breeding costs are average costs mainly based on calculations by EGGER-DANNER et al. (2000). Only 50\% of the weight recording costs were assumed to be related to breeding. No costs for semen production or storage were included since at present no progeny testing scheme for domestic AI bulls exists.

The criteria to evaluate alternative breeding strategies used in this study are defined as follows:

Annual monetary genetic gain (AMGG): Monetary superiority per year of progeny of the selected animals of one selection cycle in the breeding unit. 
Discounted profit (P): Discounted returns minus discounted breeding costs, discounted return is the monetary value of genetic superiority expressed by improved animals in the whole population (breeding and commercial unit) over the time of investment (20 years).

Table 2

Genetic standard deviations $\left(\mathrm{s}_{\mathrm{A}}\right)$ and economic weights per genetic standard deviation $\left(\mathrm{w} / \mathrm{s}_{\mathrm{A}}\right)$ in the total merit index (Genetische Standardabweichung $\left(\mathrm{s}_{\mathrm{A}}\right)$ und wirtschaftliche Gewichte pro genetischer Standardabweichung $\left(\mathrm{w} / \mathrm{s}_{\mathrm{A}}\right)$ im Gesamtzuchtwert)

\begin{tabular}{lrrr}
\hline Trait & Unit & $\mathrm{s}_{\mathrm{A}}$ & $\mathrm{w} / \mathrm{s}_{\mathrm{A}}$ \\
\hline Birth weight & $\mathrm{kg}$ & 2.35 & 0 \\
200-day weight direct & $\mathrm{kg}$ & 11.99 & 5.64 \\
Yearling weight & $\mathrm{kg}$ & 18.22 & 0 \\
Daily gain & $\mathrm{g}$ & 47 & 11.28 \\
Dressing percentage & $\%$ & 1.14 & 11.26 \\
EUROP grading score & class & 0.25 & 4.22 \\
\hline Fertility paternal & $\%$ & 5 & 7.25 \\
Fertility maternal & $\%$ & 5 & 7.25 \\
Calving ease paternal & class & 0.22 & 1.71 \\
Calving ease maternal & class & 0.22 & 1.71 \\
Stillbirth paternal & $\%$ & 2.5 & 4.00 \\
Stillbirth maternal & $\%$ & 2.5 & 4.00 \\
Longevity & day & 180 & 21.60 \\
\hline 200-day weight maternal & kg & 10.90 & 5.64 \\
\hline
\end{tabular}

Table 3

Genetic correlations and heritabilities (diagonal elements) of the traits in the total merit index (traits are scaled so that higher values are desireable) (Genetische Korrelationen und Heritabilitäten (Diagonale) der Merkmale im Gesamtzuchtwert (höhere Werte bei allen Merkmalen wünschenswert))

\begin{tabular}{|c|c|c|c|c|c|c|c|c|c|c|c|c|c|c|c|}
\hline & & 1 & 2 & 3 & 4 & 5 & 6 & 7 & 8 & 9 & 10 & 11 & 12 & 13 & 14 \\
\hline 1 & Birth weight & 0.30 & & & & & & & & & & & & & \\
\hline 2 & 200-day weight direct & 0.33 & 0.23 & & & & & & & & & & & & \\
\hline 3 & Yearling weight & 0.38 & 0.57 & 0.23 & & & & & & & & & & & \\
\hline 4 & Daily gain & 0.38 & 0.53 & 0.53 & 0.25 & & & & & & & & & & \\
\hline 5 & Dressing percentage & 0.00 & -0.38 & -0.34 & -0.04 & 0.40 & & & & & & & & & \\
\hline 6 & EUROP grading score & 0.00 & 0.00 & 0.00 & 0.04 & 0.42 & 0.15 & & & & & & & & \\
\hline 7 & Fertility paternal & 0.00 & 0.00 & 0.00 & 0.00 & -0.08 & -0.08 & 0.02 & & & & & & & \\
\hline 8 & Fertility maternal & 0.00 & 0.00 & 0.00 & 0.00 & -0.08 & -0.08 & 0.00 & 0.02 & & & & & & \\
\hline 9 & Calving ease paternal & -0.56 & -0.16 & -0.22 & -0.08 & -0.08 & 0.00 & 0.00 & 0.00 & 0.05 & & & & & \\
\hline 10 & Calving ease maternal & 0.00 & 0.00 & 0.00 & 0.08 & 0.00 & 0.00 & 0.00 & 0.00 & -0.08 & 0.05 & & & & \\
\hline 11 & Stillbirth paternal & 0.00 & 0.00 & 0.00 & -0.08 & -0.08 & 0.00 & 0.00 & 0.00 & 0.60 & 0.00 & 0.05 & & & \\
\hline 12 & Stillbirth maternal & 0.00 & 0.00 & 0.00 & 0.00 & 0.00 & 0.00 & 0.00 & 0.00 & 0.00 & 0.60 & -0.08 & 0.05 & & \\
\hline 13 & Longevity & 0.00 & 0.00 & 0.00 & 0.00 & -0.08 & -0.08 & 0.08 & 0.08 & 0.00 & 0.11 & 0.00 & 0.11 & 0.10 & \\
\hline 14 & 200-day weight maternal & -0.08 & -0.23 & 0.08 & 0.11 & -0.11 & -0.04 & -0.08 & -0.15 & -0.08 & 0.08 & 0.00 & 0.00 & 0.00 & 0.19 \\
\hline
\end{tabular}

\section{Total merit index}

For the total merit index, the appropriate traits of the total merit index applied to Austrian dual purpose cattle were used (MIESENBERGER, 1997) as well as the beef cattle specific traits birth weight, 200-day-weight direct and maternal and yearling weight. The economic weights listed in Table 2 were derived by MIESENBERGER (1997) using a herd model (AMER et al., 1994). The economic weight for 200-day- 
weight was adopted from SCHÄFER (1997). All economic weights are expressed as marginal monetary gains due to improvement of a trait by one genetic standard deviation. In the total merit index about $38 \%$ of the economic weight is on beef traits, $56 \%$ on functional traits and $6 \%$ on milk (200-day-weight maternal).

The matrix of heritabilities and genetic correlations is given in Table 3. Due to insufficient data quality and quantity of Austrian beef cattle, the parameters for beef traits and their correlations to functional traits had to be taken from literature (KOOTS et al., 1994a, 1994b; INRA \& Institute de L'Elevage, 1999). Since the matrix was not positive definite, 'BENDING' (HAYES and HILL, 1981) was applied using the program BENDPDF V1.1 (ESSL, 1991; ESSL, 1996).

\section{Alternative breeding strategies}

The effect of increasing the proportion of AI with foreign and domestic bulls as well as extending the test capacity on station and on contract farms was studied.

The proportion of AI was increased from $25 \%$ (base situation) to $50 \%$ with foreign bulls only and 25\% foreign and 25\% domestic bulls, respectively. A condition for selection of domestic AI bulls was performance testing on station, resulting in realization of the trait daily gain instead of the auxiliary trait yearling weight. As an additional breeding strategy, 2 of the 5 domestic AI bulls were only used after receiving information for slaughter and paternal functional traits from 15 crossbred progeny.

The number of bulls per year tested on stations was extended from 12 to 24 and 48 . Additionally a testing scheme for natural service bulls on contract farms with a capacity of 60,80 and 100 places per year was investigated.

\section{Results and discussion}

The annual genetic gain per trait for the base situation expressed in genetic standard deviations is shown in Table 4. Although functional traits are weighted with 56\% in the total merit index, the annual genetic gain of the majority of the functional traits is slightly negative, especially of paternal calving ease. The reason for that are the low heritabilities of functional traits in connection with their negative genetic correlations to beef traits. In an Australian study (NITTER et al., 1994) the use of the computer program ZPLAN for evaluting alternative designs in beef breeding was discussed. The results also showed that selection for growth traits only may lead to negative genetic gains in functional traits. In a second Australian study (GRASER et al., 1994), increasing levels of performance recording additionally to live weights were analysed. Fertility traits, carcass traits, calving difficulty and cow weight were considered. In no scheme calving difficulty could be improved. However, with increasing level of performance recording the genetic gain in calving difficulty became less negative. WILLAM et al. (2002) showed for dual purpose Simmental cattle that the inclusion of functional traits in the total merit index leads to higher genetic gains or reduced negative gains for fitness traits. The annual monetary genetic gain can also be increased.

For beef traits, the annual genetic gains are positive in this study, except for dressing percentage. In the Australian studies (NITTER et al., 1994; GRASER et al., 1994), dressing percentage could also not be improved due to its antagonistic relationship with growth. 
Table 4

Annual genetic gain (AGG) in genetic standard deviations $\left(\mathrm{s}_{\mathrm{A}}\right)$ for the base situation (Jährlicher Zuchtfortschritt (AGG) in genetischer Standardabweichung $\left(\mathrm{s}_{\mathrm{A}}\right)$ für die Basissituation)

\begin{tabular}{lrr}
\hline Trait & Unit & AGG in $\mathrm{s}_{\mathrm{A}}$ \\
\hline Birth weight & $\mathrm{kg}$ & 0.0732 \\
200-day weight direct & $\mathrm{kg}$ & 0.0668 \\
Yearling weight & $\mathrm{kg}$ & 0.0599 \\
Daily gain & $\%$ & 0.0746 \\
Dressing percentage & $\mathrm{g}$ & -0.0109 \\
EUROP grading score & $\%$ & 0.0059 \\
\hline Fertility paternal & $\%$ & -0.0024 \\
Fertility maternal & class & -0.0040 \\
Calving ease paternal & class & -0.0393 \\
Calving ease maternal & $\%$ & 0.0063 \\
Stillbirth paternal & $\%$ & -0.0035 \\
Stillbirth maternal & day & 0.0017 \\
Longevity & $\mathrm{s}_{\mathrm{A}}$ & -0.0002 \\
\hline 200-day weight maternal & $\%$ & 0.0082 \\
\hline
\end{tabular}

Annual monetary genetic gains are listed in Table 5 for all alternative breeding strategies (base situation bold). The annual monetary genetic gain of 1.05 EURO is very low for the base situation. In a similar Austrian study, analyzing different alternative breeding strategies for dual purpose Simmental and Brown Swiss, the annual monetary genetic gain was 12.56 EURO and 11.53 EURO, respectively (EGGER-DANNER et al., 2000).

Increasing the proportion of AI from $25 \%$ to $50 \%$ results in an improvement of AMGG by $26 \%$ (foreign AI bulls only, Table 5b) or 14\% (foreign and domestic AI bulls, Table 5c). The rise of AMGG follows improved selection intensity of natural service bulls and a higher accuracy of breeding values. This is possible without taking any measures regarding performance testing. However, the differences in AMGG between these two breeding strategies are surprising. Since foreign AI bulls are noticeably superior to the domestic AI bulls, a higher difference in AMGG was expected. Domestic AI bulls are used at a very young age as there is no progeny testing system. The result may therefore be explained by a decreased average generation interval due to the use of domestic AI bulls (5.39 years vs. 5.81 years). The discounted profit is only slightly increased, since it is related to the whole population. As the share of the purebred beef cattle population is less than $2 \%$, alternative breeding strategies which only affect the purebred population show little effect on the whole population. If only the two best of the 5 domestic bulls are used for purebreeding after receiving informations for slaughter and paternal functional traits for their progeny, the AMGG and the discounted profit are additionally increased (Table 5d). Apart from that, the annual genetic gain for dressing percentage becomes slightly positive even if performance testing on station is not extended (data not shown).

Extending the number of bulls tested on station does not result in a higher AMGG if only foreign AI bulls are used for purebreeding (Table 5a and 5b). As long as domestic bulls are only used for crossbreeding, all alternatives in performance testing regarding these bulls solely show an impact on the discounted profit by improving the quality of 
crossbred slaughter animals. In the breeding strategy with foreign and domestic AI bulls, however, the increase in capacity of performance testing on station has a positive effect on AMGG as a result of improved selection intensity (Table 5c).

Table 5

Annual monetary genetic gain (AMGG) in Euro, AMGG and discounted profit (P) in percent of base situation (\% BS) for a) $25 \%$ AI (foreign bulls), b) $50 \%$ AI (foreign bulls), c) $50 \%$ AI (25\% foreign and 25\% domestic bulls) and d) $50 \%$ AI (25\% foreign and 25\% domestic bulls plus crossbred progeny information) with 12, 24, 48 bulls tested on station (ST) and 0, 60, 80 and 100 natural service bulls tested on contract farms (CF) (Jährlicher monetärer Zuchtfortschritt (AMGG) in Euro, AMGG und diskontierter Gewinn in Prozent der Basissituation (\%BS) für a) 25\% AI (ausländ. Stiere), b) 50\% AI (ausländ. Stiere), c) 50\% AI und d) 50\% AI (je 25\% inländ. und ausländ. Stiere plus Information von gekreuzten Nachkommen) mit 12, 24 und 48 Stieren getestet auf Station (ST) sowie 0, 60, 80 und 100 Natursprungstieren getestet auf Vertragsbetrieben (CF))

a) $25 \%$ AI (foreign bulls)

\begin{tabular}{llccc}
\hline ST & CF & $\begin{array}{c}\text { AMGG } \\
\text { (Euro) }\end{array}$ & $\begin{array}{c}\text { AMGG } \\
(\% \text { BS })\end{array}$ & $\begin{array}{c}\text { P } \\
(\% \text { BS })\end{array}$ \\
\hline $\mathbf{1 2}$ & $\mathbf{0}$ & $\mathbf{1 . 0 5}$ & $\mathbf{1 0 0}$ & $\mathbf{1 0 0}$ \\
& 60 & 1.24 & 118 & 101 \\
& 80 & 1.36 & 129 & 102 \\
& 100 & 1.44 & 137 & 103 \\
\hline 24 & 0 & 1.05 & 100 & 111 \\
& 60 & 1.24 & 118 & 112 \\
& 80 & 1.36 & 129 & 113 \\
& 100 & 1.44 & 137 & 114 \\
\hline 48 & 0 & 1.05 & 100 & 119 \\
& 60 & 1.24 & 118 & 120 \\
& 80 & 1.36 & 129 & 121 \\
& 100 & 1.44 & 137 & 122 \\
\hline
\end{tabular}

c) $50 \% \mathrm{AI}$ ( $25 \%$ foreign, $25 \%$ domestic bulls)

\begin{tabular}{llccc}
\hline ST & CF & $\begin{array}{c}\text { AMGG } \\
\text { (Euro) }\end{array}$ & $\begin{array}{c}\text { AMGG } \\
(\% \text { BS })\end{array}$ & $\begin{array}{c}\text { P } \\
(\% \text { BS })\end{array}$ \\
\hline 12 & 0 & 1.20 & 114 & 103 \\
& 60 & 1.37 & 130 & 104 \\
& 80 & 1.44 & 137 & 105 \\
& 100 & 1.48 & 141 & 105 \\
\hline 24 & 0 & 1.28 & 122 & 117 \\
& 60 & 1.45 & 138 & 118 \\
& 80 & 1.51 & 144 & 118 \\
& 100 & 1.56 & 149 & 119 \\
\hline 48 & 0 & 1.34 & 128 & 127 \\
& 60 & 1.51 & 144 & 128 \\
& 80 & 1.57 & 149 & 128 \\
& 100 & 1.62 & 154 & 128 \\
\hline & & & &
\end{tabular}

b) $50 \%$ AI (foreign bulls)

\begin{tabular}{llccc}
\hline ST & CF & $\begin{array}{c}\text { AMGG } \\
\text { (Euro) }\end{array}$ & $\begin{array}{c}\text { AMGG } \\
(\% \text { BS })\end{array}$ & $\begin{array}{c}\text { P } \\
(\% \text { BS })\end{array}$ \\
\hline 12 & 0 & 1.32 & 126 & 101 \\
& 60 & 1.48 & 141 & 102 \\
& 80 & 1.54 & 147 & 102 \\
& 100 & 1.58 & 150 & 102 \\
\hline 24 & 0 & 1.32 & 126 & 112 \\
& 60 & 1.48 & 141 & 113 \\
& 80 & 1.54 & 147 & 113 \\
& 100 & 1.58 & 150 & 113 \\
\hline 48 & 0 & 1.32 & 126 & 121 \\
& 60 & 1.48 & 141 & 121 \\
& 80 & 1.54 & 147 & 121 \\
& 100 & 1.58 & 150 & 122 \\
\hline
\end{tabular}

d) $50 \% \mathrm{AI}$ ( c) plus crossbred prog. informat.)

\begin{tabular}{llccc}
\hline ST & CF & $\begin{array}{c}\text { AMGG } \\
\text { (Euro) }\end{array}$ & $\begin{array}{c}\text { AMGG } \\
\text { (\% BS) }\end{array}$ & $\begin{array}{c}\text { P } \\
\text { (\% BS) }\end{array}$ \\
\hline 12 & 0 & 1.36 & 129 & 108 \\
& 60 & 1.51 & 144 & 109 \\
& 80 & 1.58 & 150 & 109 \\
& 100 & 1.62 & 154 & 110 \\
\hline 24 & 0 & 1.44 & 137 & 122 \\
& 60 & 1.60 & 152 & 122 \\
& 80 & 1.66 & 158 & 123 \\
& 100 & 1.71 & 163 & 123 \\
\hline 48 & 0 & 1.52 & 145 & 132 \\
& 60 & 1.68 & 160 & 133 \\
& 80 & 1.74 & 166 & 134 \\
& 100 & 1.78 & 170 & 134 \\
\hline & & & &
\end{tabular}

Establishing performance testing of natural service bulls on contract farms has a positive effect on AMGG in all scenarios (Table 5a-d). In the scenario with the most comprehensive performance testing on contract farms (100 places/year) and on station (48 places/year), the AMGG is increased up to $70 \%$. Although the costs for this kind of performance testing were assumed to be relatively high (297 EURO $=2 / 3$ of the costs on station), the discounted profit is still slightly increased.

\section{Conclusions}

The annual monetary genetic gain for a beef cattle breed used for crossbreeding calculated in the base situation of this study is quite low, given that the situation was 
already optimized compared to the present situation of Austrian beef cattle breeds. The results of this study show that an increase of the proportion of AI, also using domestic AI bulls for purebreeding, as well as extending performance testing on station and contract farm of AI and natural service bulls, respectively, are desirable. Due to the moderate heritabilities of beef traits it is possible to achieve reasonable annual genetic gains except for dressing percentage as a result of the negative genetic correlation to other beef traits. As high dressing percentage is one of the main reasons for farmers with dual purpose breeds to use beef bulls for crossbreeding, this trait should be paid more attention. One possibility could be to use domestic AI bulls for purebreeding provided some information for slaughter and paternal functional traits from their progeny is available. The annual genetic gains of paternal functional traits were negative in all strategies investigated. This may be explained by the low heritabilities and their negative genetic correlations to beef traits as well as the small population size. Especially calving ease and stillbirth are, however, significant traits in beef breeding. One way of dealing with this problem could be the exclusive use of foreign AI bulls which are proven for these traits. If functional traits were not included in the total merit index, the genetic gain for these traits and the annual monetary genetic gain might be lower (WILLAM et al., 2002). Therefore these traits need to be considered when a total merit index is established for Austrian beef breeds.

\section{Acknowledgements}

Funding by the Austrian Federal Ministry of Agriculture, Forestry, Environment and Water Management, the Federation of Austrian Cattle Breeders and the Federation of Austrian Beef Breeders (Project L1041/96) is gratefully acknowledged.

\section{References}

AMER, P. R.; KAUFMANN, A.; KÜNZI, N.:

Implications for farmers and political institutions from a Swiss cattle farm model. 3rd Int. Livest. Farming System Symposium, Aberdeen, September 1-2 (1994)

BURROWS, P.M.:

Expected selection differentials for directional selection. Biometrics 28 (1972), 1091-1100

EGGER-DANNER, CH.; GIERZINGER, E.; WILLAM, A.; SÖLKNER, J.:

Zuchtplanung und Optimierung der Zuchtprogramme für die Rassen Fleckvieh und Braunvieh. Final report of the research Project L 1087/97 on behalf of the Federal Ministry of Agriculture, Forestry, Environment and Water Management, the Federation of Austrian Simmental Breeders and the Federation of Austrian Brown Swiss Breeders (2000)

ESSL, A.:

Choice of an appropriate bending factor using prior knowledge of the parameters. J. Anim. Breed. Genet., 108 (1991), 89-101

ESSL, A.:

BENDPDF. Version V1.1. http://www.boku.ac.at/nuwi/software (1996)

GRASER, H.-U.; NITTER, G.; BARWICK, S.A.:

Evaluation of advanced Industry Breeding Schemes for Australian Beef Cattle. II. Selection on Combination of Growth, Reproduction and Carcase Criteria. Aust. J. Agric. Res., 45 (1994), 1657-1669

HAYES, J.F., HILL, W.G.:

Modification of estimates of parameters in the construction of genetic selection indices ("Bending").

Biometrics, 37 (1981), 483-493

HILL, W. G.:

Prediction and evaluation of response to selection with overlapping generations. Anim. Prod., 18 (1974), 117-139

INRA \& INSTITUTE DE L'ELEVAGE: 
Repertoire des resultats de l'evaluation IBOVAL99 pour les races bovines a viande, XIII. Institut National de la Recherche Agronomique and Institut de l'Elevage, France (1999)

KARRAS, K.; NIEBEL, E.; GRASER, H.-U.; BARTENSCHLAGER, H.; NITTER, G.: ZPLAN - a PC program to optimize livestock selection programs. User's guide for ZPLAN, Version March 1997. University Hohenheim (1997)

KOOTS, K.; GIBSON, J.; WILTON J.:

Analyses of published genetic parameter estimates for beef production traits. 1. Heritability. Anim. Breed. Abstr., 62 (1994a), 309-338

KOOTS, K.; GIBSON, J.; WILTON J.:

Analyses of published genetic parameter estimates for beef production traits. 1. Heritability. Anim. Breed. Abstr., 62 (1994a), 309-338

KOOTS, K.; GIBSON, J.; WILTON J.:

Analyses of published genetic parameter estimates for beef production traits. 2. Phenotypic and genetic correlations. Anim. Breed. Abstr., 62 (1994b), 825-844

MCCLINTOCK, A. E.; CUNNINGHAM, E. P.:

Selection in dual purpose cattle populations: Defining the breeding objective. Anim. Prod., 18 (1974), 237-247

MIESENBERGER, J.:

Zuchtzieldefinition und Indexselektion für die österreichische Rinderzucht. PhD Thesis. Universität für Bodenkultur Wien (1997)

NITTER, G.; GRASER, H.-U.; BARWICK, S.A.:

Evaluation of advanced Industry Breeding Schemes for Australian Beef Cattle. I. Method of Evaluation and Analysis for an Example Population Structure. Aust. J. Agric. Res., 45 (1994), 1641-1656

SCHÄFER, C. S.:

Untersuchungen zur Zuchtplanung bei Fleischrindern am Beispiel des Fleischrinder-Herdbuches Bonn e.V. PhD Thesis. Friedrich-Wilhelms-Universität Bonn (1997)

WILLAM, A.; EGGER-DANNER, CH.; SÖLKNER, J.; GIERZINGER, E.:

Optimization of progeny testing schemes when functional traits play an important role in the total merit index. Livest. Prod. Sci. (2002, accepted)

WÜNSCH, U.; NITTER, G.; SCHÜLER, L.:

Genetic and economic evaluation of genetic improvement schemes in pigs. I. Methodology with an application to a three-way crossbreeding scheme. Arch. Tierz., Dummerstorf 42 (1999), 571-582

Received: 2002-04-02

Accepted: 2002-08-01

Authors address

Dr. BIRGIT FUERST-WALTL, Dr. ALFONS WILLAM, Prof. Dr. JOHANN SÖLKNER

Department of Livestock Sciences

University of Agricultural Sciences Vienna

Gregor Mendel-Strasse 33

A-1180 Vienna

Austria 